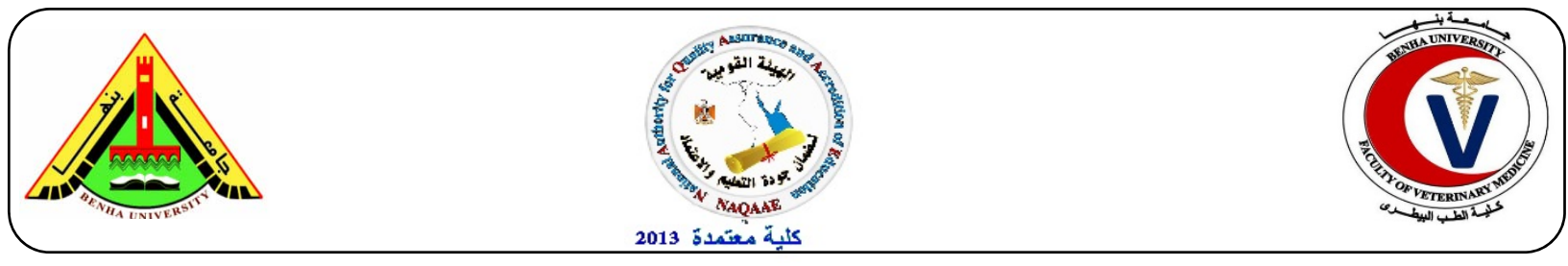

\title{
Bacteriological evaluation of half cooked chicken meat products.
}

\author{
Saad M. Saad, Abo Bakr M. Edris, Mohammed A. Hassan, Shimaa N.M. Edris \\ ${ }^{1}$ Department of Food Control, Faculty of Veterinary Medicine, Benha University.
}

\begin{abstract}
A B S T R A C T
A total of 60 random samples of half cooked chicken meat products (chicken nuggets, chicken hot wings and frozen chicken shawerma) were collected from different supermarkets at El- Dakahlyia, El-Kalyobia and El-Gharbia governorates for bacteriological examination. The obtained results indicated that there is a high significance difference $(P<0.01)$ between examined samples of chicken meat products for APC, total staphylococci count and total enterococci count as a result of product type. E.coli was isolated from $25 \%, 5 \%$ and $10 \%$ of examined samples of chicken nuggets, chicken hot wings and frozen chicken shawerma, respectively.
\end{abstract}

Keywords: Half cooked, Chicken meat, Bacteriology, Enterococci.

(http://www.bvmj.bu.edu.eg) conference issue

(BVMJ-28(2): 135-140, 2015)

\section{INTRODUCTION}

$\mathrm{C}$ hicken and chicken meat products provide animal protein of high biological value for consumers at all ages, where they contain all the essential amino acids required for human growth, higher proportion of unsaturated fatty acids and less in cholesterol value. Moreover, Poultry meat products are highly desirable, palatable, digestible and nutritious for all ages. Further processing of poultry meat involves conversion of raw poultry carcasses into value added products e.g. reconstructed products, cold cuts or breaded products. Advantages of further processing of poultry meat are improving juiciness and flavor, shelf life and water holding capacity (Sahoo, et al. 1996). Unfortunately, such products offer ideal medium as microbial growth for they are highly nutritious, have a favorable $\mathrm{pH}$, and are normally lightly salted or not salted at all (Johnston and Tompkin, 1992). Aerobic plate counts in food samples may be useful to indicate quality, shelf life and post heatprocessing contamination (GuaranTek Analytical Labo-ratories, 2003) as well as, total bacterial count is considered as an index of quality, which gives an idea about the hygienic measures during processing and helps in assessing the keeping quality of the product (Aberle et al., 2001). Food handlers are the primary source of S.aureus contamination in the processing plant. Most staphylococcal intoxications involving poultry products are related to recontamination of cooked product by food handlers, followed by improper holding temperature (NACMCF, 1997). Enterococci recognized as important nosocomial pathogens causing endocarditis, bacteremia, and central nervous system infections as well as neonatal, respiratory tract, urinary tract and other infections (Franz et al., 2011). Escherichia coli are an important organism in the food microbiology; besides being involved in food-borne gastroenteritis, it is considered as a good indicator of possible fecal contamination (Synge, 2000). Their presence in poultry cuts and its products indicates a lack of proper sanitation. 
Therefore, the objective of the current study was to determine the level of APC, Staphylococci count, Enterococci count and isolation and identification of E.coli from chicken meat products.

\section{MATERIAL AND METHODS}

\subsection{Collection of samples}

A grand total of 60 random samples of half cooked chicken meat products (20 each of chicken nuggets, chicken hot wings and frozen chicken shawerma) were collected from different supermarkets at ElDakahlyia, El-Kalyobia and El-Gharbia governorates. The collected samples were transferred directly to the laboratory in an ice box under complete aseptic conditions without undue delay and then examined bacteriologically.

\subsection{Preparation of samples (USDA, 2011)}

The samples were prepared according to the technique recommended by (American Public Health Association "APHA" (1992) as follows, twenty five grams of the frozen half cooked chicken products were transferred to a septic blender jar and homogenized with $225 \mathrm{ml}$ of $0.1 \%$ sterile buffered peptone water for 1-2 minutes at 2000 r.p.m. to give an initial dilution of 1/10.one $\mathrm{ml}$ of the initial dilution was transferred to another sterile tube containing $9 \mathrm{ml}$ of serial buffered peptone $(0.1 \%)$ to obtain the next dilution, from which further decimal serial dilutions were prepared.

\subsection{Determination of APC (USDA, 2011)}

It was done using standard plate count agar media.

\subsection{Determination of total Staphylococci} with isolation and Identification of Staphylococcus aureus (ICMSF, 1996)

It was done using Baird Parker agar media.

2.5. Determination of total Enterococci count with isolation and identification of Enterococcus spp. (ICMSF, 1996)
Bile esculine agar is recommended for isolation and identification of esculine hydrolyzing organisms such as enterococci.

\subsection{Isolation and identification of $E$. coli (APHA 1992)}

It was applied by using Eosin Methylene Blue agar media.

\section{RESULTS}

It is evident from the results recorded in table (1) that the APC (cfu/g) in the examined samples of half cooked chicken meat products varied from $1.0 \times 10^{4}$ to $3.6 \times 10^{7}$ with a mean value of $9.56 \times 10^{5} \pm$ $2.08 \times 10^{5}$ for chicken nuggets, $1.4 \times 10^{6}$ to $4.3 \times 10^{7}$ with a mean value of $6.17 \times 10^{6} \pm$ $1.21 \times 10^{5}$ for chicken hot wings, and $3.2 \times 10^{6}$ to $6.6 \times 10^{7}$ with a mean value of $8.83 \times 10^{6} \pm 1.69 \times 10^{6} \mathrm{cfu} / \mathrm{g}$ for chicken shawerma. Total staphylococci count is a good indication of inadequate sanitation and processing as well as the possibility for presence of enterotoxin producing strains as S.aureus (ICMSF, 1996b). The results recorded in table (2) revealed that the total staphylococci count ranged from $1.0 \times 10^{2}$ to $7.8 \times 10^{3}$ with an average value of $3.15 \times 10^{3} \pm 0.47 \times 10^{3} \mathrm{cfu} / \mathrm{g}$ for chicken nuggets; $1.0 \times 10^{2}$ to $4.7 \times 10^{3}$ with an average value of $1.66 \times 10^{3} \pm 0.20 \times 10^{3} \mathrm{cfu} / \mathrm{g}$ for chicken hot wings; $1.0 \times 10^{2}$ to $8.0 \times 10^{2}$ with an average value of $3.39 \times 10^{2} \pm 0.52 \times 10^{2}$ $\mathrm{cfu} / \mathrm{g}$ for chicken shawerma. Enterococci is a better indicator of fecal pollution for food than Coliforms (Davies-Colley et al.,1994). Enterococci can contaminate finished products and it is very resistant to extreme temperature, $\mathrm{pH}$ and salinity, may be multiply to high numbers and act as spoiling agents. It causes food intoxication due to production of biogenic amines which cause number of symptoms such as headache, vomiting, increasing blood pressure and even allergic reactions of strong intensity (Giraffa, 2002). Table (3) indicated that the total enterococci count in the examined samples ranged from $1.0 \times 10^{2}$ to $5.4 \times 10^{3}$ with an average value of $1.63 \times 10^{3} \pm$ $0.29 \times 10^{3} \mathrm{cfu} / \mathrm{g}$ for chicken nuggets ; 
$3.0 \times 10^{2}$ to $4.3 \times 10^{3}$ with an average value of $1.50 \times 10^{3} \pm 0.22 \times 10^{3} \mathrm{cfu} / \mathrm{g}$ for chicken hot wings; $1.0 \times 10^{2}$ to $4.1 \times 10^{3}$ with an average value of $8.71 \times 10^{2} \pm 1.94 \times 10^{2} \mathrm{cfu} / \mathrm{g}$ for chicken shawerma. E. coli may be used as an indicator microorganism because it provides an estimation of faecal contamination and poor sanitation during processing (Eisel et al., 1997). Results achieved in Table (4) indicated that E.coli was isolated from $25 \%, 5 \%$ and $10 \%$, of examined samples of chicken nuggets, chicken hot wings, and chicken shawerma, respectively.

Table (1): Statistical analytical results of Aerobic plate count/(cfu/g) (APC) in the examined samples of half cooked chicken meat products $(n=20)$

\begin{tabular}{llll}
\hline Half cooked chicken & Min. & Max. & Mean \pm S.E \\
\hline Chicken nuggets & $1.0 \times 10^{4}$ & $3.6 \times 10^{7}$ & $9.56 \times 10^{5} \pm 2.08 \times 10^{5}$ \\
Chicken hot wings & $1.4 \times 10^{6}$ & $4.3 \times 10^{7}$ & $6.17 \times 10^{6} \pm 1.21 \times 10^{5}$ \\
Chicken shawerma & $3.2 \times 10^{6}$ & $6.6 \times 10^{7}$ & $8.83 \times 10^{6} \pm 1.69 \times 10^{6}$ \\
\hline
\end{tabular}

Table (2): Statistical analytical results of total Staphylococci count/g in the examined samples of half cooked chicken meat products $(n=20)$

\begin{tabular}{cccc}
\hline Half cooked chicken & Min. & Max. & Mean \pm S.E \\
\hline Chicken nuggets & $1.0 \times 102$ & $7.8 \times 10^{3}$ & $3.15 \times 10^{3} \pm 0.47 \times 10^{3}$ \\
Chicken hot wings & $1.0 \times 10^{2}$ & $4.7 \times 10^{3}$ & $1.66 \times 10^{3} \pm 0.20 \times 10^{3}$ \\
Chicken shawerma & $1.0 \times 102$ & $8.0 \times 10^{2}$ & $3.39 \times 10^{2} \pm 0.52 \times 10^{2}$ \\
\hline
\end{tabular}

Table (3): Statistical analytical results of total Enterococci count/g in the examined samples of half cooked chicken meat products $(n=20)$

\begin{tabular}{cccc}
\hline Half cooked chicken & Min. & Max. & Mean \pm S.E \\
\hline Chicken nuggets & $1.0 \times 10^{2}$ & $5.4 \times 10^{3}$ & $1.63 \times 10^{3} \pm 0.29 \times 10^{3}$ \\
Chicken hot wings & $3.0 \times 10^{2}$ & $4.3 \times 10^{3}$ & $1.50 \times 10^{3} \pm 0.22 \times 10^{3}$ \\
Chicken shawerma & $1.0 \times 10^{2}$ & $4.1 \times 10^{3}$ & $8.71 \times 10^{2} \pm 1.94 \times 10^{2}$ \\
\hline
\end{tabular}

Table (4) Incidence and serotyping of Enteropathogenic E. coli isolated from the examined samples of half cooked chicken meat products

\begin{tabular}{lcccccc}
\hline \multirow{2}{*}{ E.coli strains } & \multicolumn{2}{c}{ Chicken nuggets } & \multicolumn{2}{c}{ Chicken hot wings } & \multicolumn{2}{c}{ Chicken shawerma } \\
\cline { 2 - 7 } & No. & $\%$ & No. & $\%$ & No. & $\%$ \\
\hline O55:H7 & - & - & - & - & 1 & 5 \\
O111:H4 & - & - & 1 & 5 & - & - \\
O119:H6 & 1 & 5 & - & - & - & - \\
O86 & 1 & 5 & - & - & - & - \\
O125:H21 & 1 & 5 & - & - & - & - \\
O124 & 1 & 5 & - & - & - & - \\
O26 & 1 & 5 & - & - & 1 & 5 \\
Total & 5 & 25 & 1 & 5 & 2 & 10 \\
\hline
\end{tabular}




\section{DISCUSSION}

The obtained results in APC come in accordance with those reported by OsmanEman (2001) and Bkheet et al. (2007) for chicken nuggets and Shaltout (2006) for chicken hot wings. Lower APC in chicken nuggets obtained by Osman -Eman (1997) and Al-Dughaym and Altabari (2010). The high total aerobic mesophilic plate count might be attributed to the contamination of the product from different sources or unsatisfactory processing as well as it may be due to un-suitable condition during storage (Zahran, 2004). APC of any food article is not a sure indicative for its safety for consumption, yet it is of supreme importance in judging the hygienic conditions under which it has been produced, handled and stored (Jay, 1997a). Also, APC is considered as index of sanitary \& quality of foods (Forsythe \& Hayes, 1998). Generally, the high bacterial counts of examined meat products may be due to contamination of flesh used for manufacture of these products, however mincing machines, grinders, equipments and knives are considered as the source of contamination of meat during processing ( Klein and Luwers, 1994). Moreover, the high storage temperature at the retail level is probably one of the principle contributing factors to high counts, particularly when the initial bacterial load is already high due to using poor quality meat cuts (ICMSF, 1996a). As well as, Addition of certain spices during manufacture of meat products may lead to marked increase in bacterial population (Sharaf, 1999). The high incidence of Staph. spp. organisms in chicken products is an indicative of unacceptable level of contamination during handling (Gad, 2004). Also, the presence of $S$. aureus in food indicates poor hygiene and improper storage conditions (Gundogan et al., 2005). Moreover, the presence of $S$. aureus in heat treated food may be due to its contamination from food handlers, inadequate cleaned equipment or post-processing contamination (Duffy et al.,
2000). Nearly similar results were obtained by Ahmed (2004) for total enterococci count. Enterococci can be used as indicators of fecal contamination. They do not only contaminate raw meats but are also associated with processed and heat-treated food materials (Wilson \& McAfee 2002; Busania et al. 2004). E.coli was previously isolated from chicken meat products by Ahmed (2004), Al-Dughaym and Altabari (2010), Sharaf and Sabra (2012), Awadallah et al. (2014).

The Presence of E.coli in examined samples indicated faecal contamination, potential food spoilage and bad sanitary conditions during production (Banwart, 1981) as well as food-borne outbreaks of gastroenteritis. Moreover, the presence of E.coli in food of animal origin is considered as indicator of faults during preparation, handling, storage or service (Tebbut, 1999).

\section{REFERENCES}

Aberle, E.D., Forrest, J., Gerrard, D.E., Mills, E.W. 2001. Principles of Meat Science $\left(4^{\text {th }}\right.$ Ed). Hunt Publishing Co., Kendall, USA.

Ahmed, A.F. 2004.Studies on cooked meat and chicken products. PhD., Thesis (Meat Hygiene), Fac. Vet. Med., Zagazig Univ., Benha Branch.

Al-Dughaym, A., Altabari, G.F. 2010.Safety and quality of some chicken meat products in Al-Ahsa markets, Saudi Arabia. Saudi Journal of Biological Science, 17:37-42.

American Public Health Association "APHA" 1992. Compendium of Methods for the microbiological examination of foods. American Public Health Association, Washington, D.C., USA. 105(4):100110.

Awadallah, M.A.I., Ahmed, H.A. , Merwad, A. M. 2014. Prevalence of non- O157 shiga toxin-producing Escherichia coli and Enterotoxigenic staphylococci in ready-to-eat meat products, handlers and consumers in 
Cairo, Egypt. Global Veterinaria 12 (5):692-699.

Banwart, G.J. 1981. Indicator organisms in: Basic food microbiology. $2^{\text {nd }} \mathrm{Ed}$. Avi. Publishing Co., West port, Connecticut, USA.

Bkheet, A.A., Rezk, M.S.H., Mousa, M.M. 2007. Study on the microbiolgical content of local manufactured poultry meat products in El-Bohira governorate. Assiut Veterinary Medical Journal, 53:115-125.

Busania, L., Grosso, M.D., Paladini, C., Graziania, C., Pantosti, A., Biavasco, F. , Capriolia, A. 2004. Antimicrobial susceptibility of vancomycinsusceptible and -resistant enterococci isolated in Italy from raw meat products, farm animals, and human infections. International Journal of Food Microbiology, 97:17-22.

Davies-Colley, R.J., Bell, R.G., Donnison, A.M. 1994. Sunlight inactivation of Enterococci and faecal Coliforms in sewage effluent diluted in sea water. Appl. Environ. Microbiol., 60:20492058.

Duffy, G., Kilbride, B., Sheridan, J.J., Blair, I.S., McDowell, D.A. 2000. A membrane immuno-flouresecnt viability staining technique for the detection of Salmonella spp. from fresh and processed meat samples. J. Appl. Microbiol., 89(4):587-594.

Eisel, W.G., Lintion, R.H., Muriana, P.M. 1997.A survey of microbial levels for incoming raw beef, environmental sources and ground beef in a red meat processing plant. J. Food Microbiol., 14:273-282.

Forsythe, S. J., Hayes, P. R. 1998. Food Hygiene, Microbiology \& HACCP. $3^{\text {rd }}$ Ed., Aspen publishers, Inc., Gaithersburg, Maryland.

Franz, C.M.A.P., Huch, M., Abriouel, H., Holzapfel, W., Galvez, A. 2011. Enterococci as probiotics and their implications in food safety. Inter. J. Food Microbiol., 151:125-140.
Gad, M.A. 2004. Microbiological evaluation of poultry meat and its products. M.V.Sc., Thesis Meat hygiene, Fac. Vet. Med., Sadat branch Minofyia Univ.

Giraffa, G. 2002. Enterococci from foods. FEMS Microbiol. Rev., 26: 163-171.

Guaran Tek Analytical Laboratories 2003. Microbiology. Web page article: http://www.guaranteklabs.com/micro biology.htm/

Gundogan, N., Citak, S., Yucel, N., Devren, A. 2005. A note on the incidence and antibiotic resistance of $S$. aureus isolated from meat and chicken samples. Meat Sci., 69(4):807-810.

International commission of Microbiological Specification for Foods "ICMSF" 1996a. Microorganisms in Food. I-Their Significance and methods of enumeration. $3^{\text {rd }}$ Ed. Univ. of Toronto Press, Toronto, Canada.

International Commission
Microbiological on
Foods 1996b.Microorganisms in Foods, Their Significance and Methods of Enumeration 2nd Ed., Univ. of Toronto Press , Toronto ,Buffalo and London.

International Organization of Standardization ISO 2002. International Organization for Standardization. No.6579. Microbiology of food and animal feeding stuffs - Horizontal methods for detection of salmonella species.

Jay, J.M. 1997a.Modern food microbiology, $4^{\text {th }}$ Ed., Chapman and Hall, International Thomson publishing, NewYork.

Johnston , R . W., Tompkin , R. B. 1992 .Meat and poultry products. "In compendium of methods for the microbiological examination of foods" P: 821 - 835 publ. American public Health Assoc. "APHA"

Klein, G., Luwers, J. 1994.Microbiological quality of fresh and stored minced 
meat of industrial origin. Wochensehrift 107(1):361-367.

Koutikoysk, A.V., Kasijanenka, A.I. 1991. Present status of salmonellosis in the Soviet Union, WHO collaboration center for veterinary sanitation and food hygiene, Moscow, USSR.

Majowicz, S.E., Musto, J., Scallan, E., Angulo, F.J., Kirk, M., O'Brien, S.J., Jones, T.F., Fazil, A. , Hoekstra, R.M. 2010. The global burden of nontyphoidal salmonella gastroenteritis. Clin. Infect. Dis., 50(6):882-889.

National Advisory Committee on Microbiological Criteria for Foods "NACMCF" 1997. Generic HACCP application in broiler slaughter and processing. J. Food prot., 60:579.

Osman-Eman, M.S. 1997. Bacteriological evaluation oh heated chicken and chicken meat products with special reference to enterotoxigenic staphylococci isolates. M.V.Sc. Thesis (Meat Hygiene), Fac. Vet. Med., Cairo Uni.

Osman-Eman, M.S. 2001. Quality assurance of locally dressed broiler's cuts and their products. Ph.D. Thesis (Meat Hygiene), Fac. Vet. Med., Cairo Univ.

Rasschaert, G., Houf, K., Imberechts, H., Grijspeerdt, K., De Zutter, L., Heyndrickx, M. 2005. Comparison of five repetitive-sequence-based PCR typing methods for molecular discrimination of salmonella enterica isolates. J. Clin. Microbiol., 43:36153623.

Sahoo, J., Samoon, A.H., Sapcota, D. 1996. Recent developments in further processed poultry meat products. Indian Food Indust. , 15(2):30 - 36.

Shaltout, F.A. 2006. Microbiological aspect of semi-cooked chicken meat products. Benha, Vet. Med. J., 13(2): 15-25.

Sharaf, S.H. 1999. Bacteriological studies on meat and meat products with special reference to salmonella and shigella serotypes. Ph.D. Thesis (meat hygiene), Fac. Vet. Med. Moshtohor, Zahazig University (Benha Branch).

Sharaf, E.M., Sabra, S.M. 2012. Microbiological loads for some types of cooked chicken meat products at Al-Taif Governorate, KSA .World Applied Sciences Journal, 17(5):593597.

Synge, B.A. 2000.Verocytotoxin producing E.coli, a veterinary review. J. Appl. Microbiol. Symposium. Suppl., 88: 315-375.

Tebbut, G. M. 1999. Microbiological contamination of cooked meats and environmental site in premise selling both raw and cooked meat products. Inter. J. Environm. Health Research 3(4):209-216.

Wilson, I.G., McAfee, G.G. 2002. Vancomycin-resistant enterococci in shellf fish, unchlorinated waters and chicken. International Journal of Food Microbiology, 79:143-151.

Zahran, D.A. 2004. Using gamma irradiation as an option for controlling bacteria contaminating some foods of animal origin. $\mathrm{PhD}$., Thesis of Meat Hygiene, Faculty Veterinary Medicine, Zagazig University (Banha Branch), Banha, Egypt. 